\title{
The Value Foundation of Exchange Rate
}

\author{
Song Shuli \\ School of International Business Administration \\ Zhejiang International Studies University \\ Hangzhou, China \\ e-mail: songshuli2012@126.com
}

\begin{abstract}
The theory of international value is the deepening development and application of Marx's theory of labor value, and also the basis for revealing the exploitative relationship of international capitalism in the world economic globalization. But so far the major challenges that have been faced by Marx's theory of labor value and Marxism international economics are how to quantitatively study on the fundamental principle that the international value is decided by the necessary labor time of the whole world and reasonable to explain the contemporary complex international economic problems with the theory of international value. On the basic assumptions of Marxist economics, the paper analyses the specific expressions of exchange rate in gold and silver money in circulation and in the notes in circulation, in turn, and derivates the general expression of exchange rate. Then it shows that the world labor is the value foundation of exchange rate, and the exchange rate must depend on the world labor which can creates the international value of export commodities, and change with the change of necessary world labor time.
\end{abstract}

Keywords-exchange rate; world labor; international value; labor parity; virtual labor parity

\section{INTRODUCTION}

The theory of international value ${ }^{1}$ is the deepening development and application of Marx's theory of labor vale u(Marx, 2004), and also the basis for revealing the exploitative relationship of international capitalism in the world economic globalization(He Ganqiang, 2013; Liu Hang, Zhang Yuwei, 2014). But so far the major challenges that have been faced by Marx's theory of labor value and Marxism international economics are how to quantitatively study on the fundamental principle that the international value is decided by the necessary labor time of the whole world and reasonable to explain the contemporary complex international economic problems with the theory of international value(Smith ,2008;Song Shuli,2012,2013; Li Zhen,2013). ${ }^{1}$ The labor nature and existence of the substance of international value is the basis of labor to discover the works of the capitalist of production in the world market according to the logic of labor value under the conditions of modification of the law of value. As a general

\footnotetext{
${ }^{1}$ The theory of international value has long been the most frequency to debate and difficult to innovate. So it is the basic to further innovate and develop the theory through clarifying the research venation and foci on international value, furthermore, summarizing the progress and the problem of the current study.
}

form of domestic value, the substance of international value has the basic properties of the substance of domestic value which is the broader social labor and contains two meanings of broader socially necessary labor. Further, the fundamental conditions for the existence of the substance of domestic value also are bound to change in international economic relations, but cover the international value. It concludes that the substance of international value is the application of dual natures of labor. Furthermore, Feng Jinhua(2012, 2013) developed a mathematical expression of domestic value to explain that two kinds of socially necessary labor time codetermine the value of commodities. That expression is as follows:

$$
z_{i}=\frac{p_{i}}{p_{a} Q_{a}+p_{b} Q_{b}+p_{2} Q_{2}+\mathrm{L}+p_{n} Q_{n}} L=\frac{p_{i}}{\sum_{j=a, b, 2, \mathrm{~L}, n} p_{j} Q_{j}} L
$$

Further instructions, first, the industry 1 is cogeneration mode that produces two kinds of goods, a and b; second, other industries are all single production mode that produces commodity $i(i=2, \mathrm{~L}, n)$ and the output is $Q_{i}(i=2, \mathrm{~L}, n)$; third, the industry $n$ produces metallic money; fourth, according to the labor theory of value $L=\sum_{j=a, b, 2, \mathrm{~L}, n} w_{j} Q_{j}$ represents the total amount of domestic values or labor; fifth, according to the principle of exchange of equal values, $z_{i}=p_{i} z_{n}$, $i=a, b, \mathrm{~L}, n$. Then he further get the values of any industry, as follows:

$$
Z_{i}=z_{i} Q_{i}=\frac{p_{i} Q_{i}}{\sum_{j=a, b, 2, \mathrm{~L}, n} p_{j} Q_{j}} L
$$

The above expression can further be decomposed into as follows:

$$
z_{i}=\frac{Z_{i}}{Q_{i}} \text { and } Z_{i}=\frac{p_{i} Q_{i}}{\sum_{j=a, b, 2, \mathrm{~L}, n} p_{j} Q_{j}} L
$$

On the basis of Feng Jinhua's value model, the paper explain the decision and change of exchange rate with the theory of international value from Marx.

\section{II.THE EXCHANGE RATE OF METALLIC} CURRENCY

\section{A. The Basic Assumptions}

\section{1) International exchange of equal values}


Now suppose that one country A will supply the gold and the other country B will supply the silver. The In addition, suppose the export commodity a produced by country A exchange the silver from country B at equal values and the export commodity $b$ produced by country $\mathrm{B}$ exchange the gold from country $\mathrm{A}$ at equal values. Furthermore, and the gold exchanges the silver at equal values. The above conditions can be shown with algebraic expression:

$w_{A a}=p_{s a} w_{s}$

$w_{B b}=p_{g b} w_{g}$,

$w_{g}=p_{s g} w_{s}$

Further instructions, $w_{A a}, w_{B b}, w_{g}$, and $w_{s}$ represent export commodity $a$ and $b$, unite international value of international money gold and silver, respectively.

$p_{s a}$ and $p_{g b}$ represent corresponding international price

of export commodity, respectively. $p_{s g}$ represents the international price of gold in terms of silver.

In order to facilitate the analysis, we define the direct quotation with gold as quoted currency and the indirect quotation with silver as quoted currency. So if using the direct quotation, the equation set (1) aretransformed into the forms as follows:

$w_{A a}=p_{s a} w_{g} / p_{g b}$,

$w_{B b}=p_{g b} w_{g}$,

$w_{s}=w_{g} / p_{s g}$

While if using the indirect quotation, the equation set (4) are transformed into the forms as follows:

$w_{A a}=p_{s a} w_{s}$,

$w_{B b}=p_{g b} p_{s g} w_{s}$,

2) The amounts of international value equals to the amounts of world labor

This basic assumption can be shown with algebraic expression:

$w_{A a} Q_{A a}+w_{B b} Q_{B b}+w_{g} Q_{g}+w_{s} Q_{s}=W=L$

In order to facilitate the analysis, let a substitute for $\mathrm{Aa}$ and $\mathrm{b}$ substitute for $\mathrm{Bb}$, then the equation (4) is modified as follows: quantities of gold and silver respectively are $Q_{g}$ and $Q_{s}$.

$w_{a} Q_{a}+w_{b} Q_{b}+w_{g} Q_{g}+w_{s} Q_{s}=W=L$

\section{B. The International Value of Unit Money and the Form of Exchange rate}

We can confirm separately the unit international value of international money gold and silver with the direct quotation method bringing the equation set (5) into (8), as follows:

$$
\begin{aligned}
& w_{g}=\frac{1}{p_{s a} Q_{a} / p_{s g}+p_{g b} Q_{b}+Q_{g}+Q_{s} / p_{s g}} L, \\
& w_{s}=\frac{1}{p_{s a} Q_{a} / p_{s g}+p_{g b} Q_{b}+Q_{g}+Q_{s} / p_{s g}} \frac{1}{p_{s g}} L
\end{aligned}
$$

Further instructions, $i=a, b, g, s, p_{i}$ represents the international price of gold, $\sum_{j=a, b, g, s} p_{j} Q_{j}$ represents the total international price of gold in the international exchange.

Similarly, we also confirm separately the unit international value of international money gold and silver with the indirect quotation method bringing the equation set (6) into (8), as follows:

$$
\begin{aligned}
& w_{g}=\frac{p_{s g}}{p_{s a} Q_{a}+p_{g b} p_{s g} Q_{b}+p_{s g} Q_{g}+Q_{s}} L, \\
& w_{s}=\frac{1}{p_{s a} Q_{a}+p_{g b} p_{s g} Q_{b}+p_{s g} Q_{g}+Q_{s}} L
\end{aligned}
$$

Further instructions, $i=a, b, g, s, \stackrel{\circ}{p_{i}}$ represents the international price of silver, $\sum_{j=a, b, g, s} \bar{p}_{j} Q_{j}$ represents the total international price of silver in the international exchange.

So the rate of gold to silver is as follows:

$$
w_{g} / w_{s}=\frac{L / \sum_{j=a, b, g, s} p_{j} Q_{j}}{p_{s} L / \sum_{j=a, b, g, s} p_{j} Q_{j}}=\frac{\vec{p}_{g} L / \sum_{j=a, b, g, s} \bar{p}_{j} Q_{j}}{L / \sum_{j=a, b, g, s} \bar{p}_{j} Q_{j}}
$$

Further simplify the equation (9) to get the below equation:

$w_{g} / w_{s}=1 / p_{s}=\frac{p_{g}}{p_{s g}}$

Next, according to the same deducing methods, the rate of gold to silver can be extended to general case that there are more than two nations and two export commodities in international trade. First, using the direct quotation, we can get the rate of gold to silver as follows:

$w_{n} / w_{n-1}=\frac{L / p_{1} \sum_{X=1}^{m} Q_{X 1}+\ldots+p_{n} \sum_{X=1}^{m} Q_{X n}}{p_{n-1} L / p_{1} \sum_{X=1}^{m} Q_{X 1}+\ldots+p_{n} \sum_{X=1}^{m} Q_{X n}}=1 / p_{n-1}$ 
Further instructions, the last special export commodity $n$ is the international money gold, and the special export commodity $n-1$ is the international money silver.

Second, using the indirect quotation, we can also get the rate of gold to silver as follows:

$$
w_{n} / w_{n-1}=\frac{\vec{p}_{n} L / \stackrel{\circ}{p}_{1} \sum_{X=1}^{m} Q_{X 1}+\mathrm{L}+\vec{p}_{n} \sum_{X=1}^{m} Q_{X n}}{L / \stackrel{\circ}{p}_{1} \sum_{X=1}^{m} Q_{X 1}+\mathrm{L}+\vec{p}_{n} \sum_{X=1}^{m} Q_{X n}}=\vec{p}_{n}
$$

In addition, we can get further the rate relation as follows:

$$
w_{n} / w_{n-1}=1 / p_{n-1}=\bar{p}_{n}=p_{s g}
$$

It is worth stressing that, the exchange rate of gold to silver is not the ratio of two weights which is named mint parity, also not the ratio of two symbolic weights which is named gold parity, but the ratio of two socially necessary labor times which can be named labor parity. It shows that the international value of international money is the foundation of exchange rate, in other words, the world labor must determine the exchange rate.

\section{THE EXCHANGE RATE OF PAPER}

\section{CURRENCY}

According to the theories of circulation of metallic currency and paper money from Marx, we can get the unit international value of any two paper money, for example, the dollar USA and pound $G B P$, but with one important note. The paper money has no labor value in and of itself, and only represents certain labor value.

On hand, we discuss the law of the circulation of international paper money. It is clear that the amount of international paper currency in circulation only represents the total amount of international values of necessary metallic money in international trade. In order to facilitate the analysis, $w_{U}$ and $w_{G}$ represent the international values of $U S A$ and $G B P$, respectively. Furthermore, $w_{G}=p_{U G} w_{U} ; Q_{U}$ and $Q_{G}$ represent the amount of $U S A$ and $G B P$ in circulation for international trade, respectively; $v_{U}$ and $v_{G}$ represent the velocity of $U S A$ and $G B P$ in circulation; suppose that there should be a single currency gold in international trade, $w_{n}$ represents the international value of gold, $Q_{n}^{d}$ represents the currency in circulation, and $v_{n}$ represents the velocity of gold in circulation. Then get the formula as follows:

$$
v_{U} w_{U} Q_{U}+v_{G} w_{G} Q_{G}=v_{n} w_{n} Q_{n}^{d}
$$

This is easy to understand: $v_{U} w_{U} Q_{U}+v_{G} w_{G} Q_{G}$ represents the total amount of international values of international paper money and $v_{n} w_{n} Q_{n}^{d}$ represents the total amount of international values of international metallic money in international exchange.

Now according to $w_{G}=p_{U G} w_{U}$, we can get the new formulas as follows:

$$
\begin{aligned}
& \left(v_{U} Q_{U}+v_{G} p_{U G} Q_{G}\right) w_{U}=v_{n} w_{n} Q_{n}^{d} \\
& \left(\frac{1}{p_{U G}} v_{U} Q_{U}+v_{G} Q_{G}\right) w_{G}=v_{n} w_{n} Q_{n}^{d}
\end{aligned}
$$

On the other hand, we discuss the law of the circulation of metallic money. Marx showed that aggregate prices of commodities determine the amount of currency in circulation, and the two amount must be equal. So the same law in international trade is as follows:

$Q_{n}^{d}=\frac{\sum_{i=1}^{n-1} p_{i} Q_{i}}{v_{n}}$

Further instructions, $\quad p_{i}^{\mathbf{l}}$ represents any international price of export commodities with the dollar USA and $\sum_{i=1}^{n-1} p_{i} Q_{i}$ means the aggregate international prices of export commodities.

Combine the law of the circulation of international paper money and metallic money, and the expression of unit international value of gold, then get the expression of international value of paper money as follows:

$$
\begin{gathered}
w_{U}=\frac{w_{n}}{v_{U} Q_{U}+p_{U G} v_{G} Q_{G}} \\
=\frac{\sum_{i=1}^{n-1} p_{i}^{4} Q_{i}}{\left(v_{U} Q_{U}+p_{U G} v_{G} Q_{G}\right)\left(p_{1} \sum_{X=1}^{m} Q_{X 1}+\mathrm{L}+p_{n} \sum_{X=1}^{m} Q_{X n}\right)} L \\
w_{G}=\frac{\frac{1}{p_{n} \sum_{i=1}^{n-1} p_{i} Q_{i}} v_{U} Q_{U}+v_{G} Q_{G}}{p_{U G}} \\
=\frac{p_{U G} \sum_{i=1}^{n-1} p_{i} Q_{i}}{\left(v_{U} Q_{U}+p_{U G} v_{G} Q_{G}\right)\left(p_{1} \sum_{X=1}^{m} Q_{X 1}+\mathrm{L}+p_{n} \sum_{X=1}^{m} Q_{X n}\right)} L
\end{gathered}
$$

Further instructions, $w_{U}$ represents the unit international value of U.S. dollar, $w_{G}$ represents the unit international value of pound sterling, $\sum_{i=1}^{n-1} p_{i} Q_{i}$ represents the total international price of export commodities in dollars, $\sum_{i=1}^{n-1}{ }_{p_{i}} Q_{i}$ represents the total international price of export commodities in pounds, $v_{U} Q_{U}+p_{U G} v_{G} Q_{G}$ represents the amount of paper money in circulation with dollars pricing in foreign trade, $v_{U} Q_{U}+v_{G} Q_{G} / p_{U G}$ represents the amount of paper money in circulation with pounds pricing in foreign trade, $p_{1} \sum_{X=1}^{m} Q_{X 1}+\mathrm{L}+p_{n} \sum_{X=1}^{m} Q_{X n} \quad$ represents the total 
international price of export commodities with gold So the rate of pound to dollar is $w_{G} / w_{U}=p_{U G}$, and the rate of dollar to pound is $w_{U} / w_{G}=1 / p_{U G}$. It can be named virtual labor parity depending on labor parity.

\section{THE EXCHAGE RATE OF GENERAL}

\section{INTERNATIONAL MONEYS}

Based on the above analysis, we can get the general rate of one international money to the other international money as follows: $w_{i} / w_{j}=p_{j i}$, and $i, j$ is a positive integer, and $i \neq j$. Further instructions, if $i$ and $j$ is metallic international currency, $w_{i} / w_{j}$ is named labor parity, and if $i$ and $j$ is international credit money, $w_{i} / w_{j}$ is named virtual labor parity. Then suppose that $i$ is foreign currency and $j$ is domestic currency, so $p_{j i}$ is the international price of foreign currency under the direct quotation, and $1 / p_{j i}$ is the international price of foreign currency under the indirect quotation. This is obviously a reciprocal relationship between two quotations. So that shows that the rate of any international moneys depends on international value and world labor.

Next we can discuss the change of exchange rate(Lee Chai,2004,2006). Because the above shows that the rate depends on the ratio of two international values contained in international currencies, so it must change with the change of the international values. Specifically speaking, first, under the steady international value contained in foreign currency, the rate is inversely proportional to the international value contained in domestic currency with direct quotation, and proportional with indirect quotation. Second, under the decreased international value contained in foreign currency, if the international value contained in domestic currency also decreased, but more than in foreign currency, the rate must increase with direct quotation; if the international value contained in domestic currency also decreased, but less than in foreign currency, the rate must decrease with direct quotation; if the international value contained in domestic currency can increase, the rate must decrease in any case. In other words, if the international value contained in domestic currency also decreased, and more than in foreign currency, the rate must increase with indirect quotation; if the international value contained in domestic currency also decreased, but less than in foreign currency, the rate must increase with indirect quotation. Last, under the increased international value contained in foreign currency, the change of exchange rate is contrary to the second. pricing, L represents the amount of world labor.

\section{V.CONCLUSIONS}

The research thoughts and structure is based on Marx's labor theory of value, following the basic logic of value research and supposing that the law of value has not produced qualitative changes, and according to the distribution of the total amount of labor in proportion, apply the general equilibrium expression of international value to explain the different effects on the decision and changes of international value(Feng Jinghua,2012,2013). Then explain the decision and changes of exchange rate with the theory of international value. It shows that both the labor parity and virtual labor parity show that the exchange rate must depend on the world labor which can creates the international value of export commodities, and change with the change of necessary world labor time. Furthermore, the change of the rate is affected by both the international values of two international currencies, so is inconsistent with the international value of any international value. For China, achieve the comparative advantages of core industries to implement the mutual benefit and win-win strategy, and under national macro-control promote the national competitive advantages and stick to the policy of gradual exchange rate reform, then produce more international value.

\section{ACKNOWLEDGEMENT}

This research was supported by Hangzhou Philosophy and Social Science planning project (Grant NO. B14YJ13).

\section{REFERENCES}

[1] Marx, Das Kapital, Volume I, People's Publishing House, 2004.

[2] Marx, Das Kapital, Volume II, People's Publishing House, 2004.

[3] Marx, Das Kapital, VolumeIII, People's Publishing House, 2004.

[4] He Ganqiang, Analysis on International Law of Value and Its Functionary Features, China Review of Political Economy, Vol.4, No.1, Jan., 2013

[5] Liu Hang, Zhang Yuwei, The Contemporary Development, The Economist, Jun, 2014

[6] Song Shuli, The Scientific Analysis for Marx's Labor Theory, Contemporary Economic Research, September, 2012.

[7] Smith, N. , Uneven Development (3rd edn), London: University of Georgia Press, 2008.

[8] Song Shuli, New Interpretations of the Dynamic Games of Marx's Thought on International Unequal Exchange, Contemporary Economic Research, May, 2013.

[9] Li Zhen, Carbon Leakage Model and Carbon Benefit-cost Estimation Framework under International Industrial Transfer, Journal of Finance and Economics, Jun., 2013.

[10] Feng Jinhua, The Distribution of Total Quantity of Social Labor and Determination of Magnitude of Value, Economic Review. No.6. 2013.

[11] Feng Jinhua, The Value Foundation of General Equilibrium Theory, Economic Research Journal, Jan., 2012.

[12] Feng Jinhua, The Determination of Value in Joint Production, Social Science Front, Nov., 2012

[13] Feng Jinhua, Single Production, Joint Production and Determination of Value, Study \& Exploration, Jan., 2013.

[14] Lee Chai, On Currency Exchange Rates Determination in the Lightof Marx's Labor Value Theory, The Third Australian Society of Heterodox Economists Conference, December, University of New South Wales, 2004. 
[15] Lee Chai, On a new Approach to Marx Labo $r$ Theory of International Valu, The Second Conference of International Forum on the Comparative Political Economy of Globalization, September, School of Economics, Renmin University of China, 2006.

[17] Samuelson,P.A.,The'Transformation'from Marxian'Values'to Competitive Prices: A Process of Rejection and Replacement, Proceedings of the National Academy of Sciences,Jan.,1970.
[16] Samuelson, P. A. ,Wages and Interest: A Modern Dissection of Marxian Economic Models, The American Economic Review, Jun,1957,

[18] Samuelson, P. A. , Understanding the Marxian Notion of Exploitation: A Summary of the So-Called Transformation Problem Between Marxian Values and CompetitivePrices, Journal of Economic Literature, Feb. 1971. 